\title{
Teachers' Perception of the National Ideology of Kemalism and Its Effects on Kurdish Pupils
}

\author{
Adem Ince $^{i}$ \\ Faculty of Education, Siirt University, Turkey
}

Copyright $(2019$ by authors, all rights reserved. Authors agree that this article remains permanently open access under the terms of the Creative Commons Attribution License 4.0 International License

\begin{abstract}
This paper is based on an empirical study examining Turkish and Kurdish teachers’ perception of the national ideology of Kemalism and its effects on Kurdish pupils. A semi-structured interview was conducted with 30 teachers working in the east/southeast provinces of Turkey, which are predominantly inhabited by Kurds. The findings revealed that the Kemalist ideology has serious negative effects on Kurdish pupils, as it directly excludes and alienates the Kurdish identity. This paper also showed that the dominance of Kemalism in education seems to trigger a lot of other issues existing in society such as the exclusion of non-Turks and polarisation.
\end{abstract}

Keywords Kemalism, Kurdish Question, Turkish Educational System, Ideology

\section{Introduction}

Kemalism has been the official national ideology of Turkey since its foundation, which has flourished in Turkey after Atatürk died, and remains the official ideology of the Turkish state (Bora, 2017), maintaining its significance even under the rule of conservative parties for years, such as current Ak Party (Justice and Development Party) which is known for its anti-Kemalist position. The ideology of Kemalism is embedded in the state philosophy of Turkey. Therefore, one could easily see 'the omnipresence of Atatürk images' everywhere in the public sphere, from hospitals to schools, and from private businesses to the streets. Thus, 'the visual symbolism' is actually a significant part of Atatürk cult (Özyürek, 2006). Likewise, as Glyptis (2008: 356) also notes:

Atatürk's face appears on posters behind supermarket counters, in barbershops and video stores, in bookshops and banks; Atatürk talismans even dangle from car mirrors, while Atatürk pins adorn lapels. And even the Turks who do not join in with such spontaneous commemorations know how to 'read' the Atatürk semiotic universe.
The cult of Atatürk was initially established in the 1930s when Atatürk was still alive. For example, the first examples of statues/monuments across Turkey were encouraged by Atatürk himself as he clearly made himself out to be the unquestionable leader, who is referred as the 'eternal chief' (ebedîs şef) even during his own time. Having said that the establishment of the cult of the Atatürk personality was completed by his followers (including the Turkish armed forces that are fierce defender of the Kemalist ideology) after his death (see Zürcher, 2007).

\section{Kemalism}

Kemalism is an ideology primarily based upon 'Atatürk's Principles', which is also referenced in the Turkish Constitution: Republicanism (Cumhûriyetçilik), Populism (Halkçılık), Laicism (Laiklik), Revolutionism (Devrimcilik), Nationalism (Milliyetçilik) and Statism or State Socialism (Devletçilik). As mentioned by Yavuz and Esposito (2003), Kemalism was systemised by Mustafa Kemal in the Fourth Congress of the CHP in 1935, when the six principles were acknowledged as the main principles of the CHP and the Turkish state. Even though there are different interpretations of Kemalism among adherents, these 6 principles are considered to be the fundamental tenants agreed on unanimously by Kemalists.

Apart from Atatürk's principles, in order to understand the philosophy of the Kemalist ideology it is vital to comprehend the ideas shaping Atatürk's thoughts, thus Kemalism. For instance, Insel (2004) suggested that the prevailing characteristic of Kemalism is actually 'authoritarianism'. To him, the ideal political system for Kemalism is an 'authoritarian democracy', which promotes the disciplined and ordered society, expecting an unconditional obedience to state authority, adopting the understanding of limited freedom under the absolute authority of the state. Uyar (2004) also highlighted the importance of the 'authoritarianist' feature of all existing versions of Kemalism. Moreover, Çandar (2000) further adds another point by highlighting the inspiring 
phenomenon for Kemalism: "In their secularism (and in their statecraft generally), Atatürk and the Kemalist elites were powerfully influenced by French ideas, particularly those of French Revolutionary Jacobinism”. İnsel (2004) also believes that the French Revolution and Jacobinism greatly affected Kemalism in many ways. In this regard, it is true that the Kemalist modernisation project represented a rather 'authoritarian' and 'Jacobenist' model which considered a "top-down transformation" crucial in order to change society. Generally speaking, as Ünder (2004: 142) puts it, "The political method of Atatürk is Jacobenist, his attitude to people is paternalist".

After Atatürk died, the development of the Kemalist ideology and the institutionalisation of Kemalism have been completed over time. Even though some of the developments such as the rise of the Communist or Islamist ideology were interpreted to be undermining the Kemalist ideology and the role of Atatürk in Turkey, the Turkish armed forces played a key role in re-establishing and consolidating the Kemalist ideology within state mechanism. Thus, Kemalism still remains a strong/privileged and an official ideology in today's Turkey, dominating many areas ranging from the Turkish Constitution to the educational system. This is because the military in Turkey played an important role in designing the new Republic. Harris (1965: 55), for example, stated that "it was the military and not the party that became the fountainhead of progressive practices; an organ for the spread of the reforms considered vital. Further it was the ultimate base of power for the regime, the guardian of its ideals". With this in mind, the army was not only guarding the frontiers of Turkey, but also the Kemalist secularist characteristics of the Turkish state, too. As Biltekin (2007: 101) put it, the Turkish armed forces have been "the forerunner of the [Kemalist] reforms, and the guardian of the regime, [therefore] the army could not simply be out of politics”.

\section{Kemalist Nationalism}

Apart from the aforementioned points, as mentioned earlier in this chapter, Gökalp was also a prominent sociologist/thinker who is seen "the father of Turkish nationalism” (Melson, 1990: 164), systemising Turkish nationalism in the late Ottoman period, defending it against the ideas of Islamism and Ottomanism. Because his ideas significantly affected Atatürk, thus, the nation-building policies of the Kemalist modernisation project in the single-party period, he has been portrayed as part of the "cult of nationalism and modernisation" (Erickson, 2001: 97). However, even though it is a common assumption that Mustafa Kemal's nationalist ideas were 'totally' inspired by Gökalp, there appears to be a clear distinction between the two. As Turan (1999) and Belge (2004) noted, Gökalp was not in favour of racism, defending the version of cultural (Turkish) nationalism that should neither be aggressive nor imperialist, while the Kemalist version of nationalism included a 'racist' rhetoric. To illustrate this, as mentioned earlier, Âfet İnan's anthropological research commissioned by Atatürk himself - on 'cephalometry' (the measurement of living people's cranium ${ }^{1}$ ) and 'craniometry' (the measurement of dead people's cranium) shows the racist characteristic of the Kemalist version of Turkish nationalism (Guttstadt, 2013). Therefore, even though Atatürk was influenced by Gökalp's nationalist ideas, the 'racial-based definition of the Turkish nation' and 'racism' seems to be distinctive features of Kemalist nationalism.

\section{The Current Situation in Turkey}

In the existing curriculum in Turkish education, the cult of Atatürk's personality and his ideology, Kemalism, are the two fundamental elements that are promoted to students. Students are expected to embrace Atatürk's world-view, and they are even supposed to interpret different phenomena according to his ideas. Kemalism is considered to be a taboo which should not be questioned within the classroom environment according to Article 11 of the Basic Law on Education (Ministry of National Education, 2012), even though one of the most important educational attainments emphasised in schools and often in textbooks is 'critical thinking' (eleștirel düşünce). This is somewhat ironic, because students develop an interesting relationship with Atatürk. For example, in 2012, there was a study conducted regarding the cult of Atatürk. In one of the questions posed to students, 51 out of 60 students said, 'We owe our lives to him.' (Elmas, 2007: 42). As explained by Özyürek (2006), Atatürk's cult of personality has a long historical context, which is still defended today in daily life. Thus, the perception of students always reinforced by materials in schools, the wider political discourse, and statues and portraits in daily life too.

Because Kemalism continues to dominate the education system in Turkey (Ince, 2012), as well as its influence in politics and daily life (Mateescu, 2006), this paper thus seeks to understand how it, and the themes that are related to the cult of Atatürk in the curriculum, are viewed by teachers with predominantly Kurdish students. Furthermore, and more specifically, this study also looks at the effects of Kemalism on the Kurdish pupils and how the ideology-driven education system affects the stance of Kurdish pupils towards the Turkish state.

\section{Methods}

A qualitative research method has been selected for this research, as this helps the researcher compare different

1 The main part of the skull. 
perceptions of participants, and thus interpret their attitudes and experiences in terms of the effects of Kemalism within education on Kurdish pupils. As noted by Denzin and Lincoln (2000), qualitative research also enables the researcher to be able to see any social phenomenon through the lenses of the actors, which are teachers in this paper.

\section{The In-Depth Semi-Structured Interview}

A semi-structured interview method is the most used technique in qualitative research. This approach allows the researcher to explore the issue in-depth, and to probe and ask questions spontaneously right after participant responses, something that creates a certain degree of flexibility during the interview process (Gray, 2004). Probing, in this case, is a way of investigating any social phenomenon deeply from the perspective of the interviewee. However, having 'key themes and sub-questions' in advance... [gives] the researcher a sense of order from which to draw questions from unplanned encounters' (David and Sutton, 2004). Taking into consideration all of these features, a semi-structured interview was considered as the most adequate method of data collection for this research in order to reflect people's experiences, attitudes and perceptions in a more adequate way.

\section{The Participants}

30 teachers have been interviewed for this research, who works in the east and southeast of Turkey. The provinces of Siirt, Mardin, Van, Batman, Tunceli, Bingöl, Diyarbakır, Şırnak, Bitlis, Muş, Ağrı and Hakkari, which are located in both Eastern Anatolian and Southeastern Anatolian regions of Turkey were selected as the research site. This is because these provinces are predominantly inhabited by Kurds. Besides, these places are where the Kurdish culture is still alive and visible in many respects. Another important detail is that the Kurdish language is spoken in daily life in these provinces more than other provinces in Turkey.

McDowall (2003) argued that 23\% of Turkey's population is Kurdish, whereas the CIA World Factbook (2014) suggested that there are approximately 14 million Kurds in Turkey, which roughly constitutes $18 \%$ of the whole population. However, Sirkeci (2006) warned against potential biases in studies and censuses, and cautiously noted that the closest figure would certainly be above $17.8 \%$. More specifically, a more recent survey suggested that around $76 \%$ of the Kurds live in the east and southeast of Turkey (KONDA, 2010).

Even though these provinces have also been subjected to the homogenising policies of Turkey's nation-building project resulting from the Kemalist nationalist doctrine (Gambetti, 2008), they continue to reflect Kurdish culture in daily life. This is partly due to the fact of the municipalities of these provinces have rejected the Turkification policy via institutional means in the recent past, and most of these provinces were run by the pro-Kurdish People's Democratic Party (HDP, Halkların Demokratik Partisi) for a long time. Apart from the municipal elections in 2009 and 2014, the HDP was also able to gain the majority of the votes here in the June 2015 elections.

\section{Sampling}

Purposive sampling (also known as judgmental), a form of non-probability sampling, has been used for the fieldwork of the research in order to avoid the probability of biases in the sample. Purposive sampling is to select a sample 'on the basis of your own knowledge of the population, its elements, and the nature of your research aims' (Babbie, 1990: 97). Likewise, Mason (1996: 93) also stated that 'purposive sampling involved selecting individuals on the basis of their relevance to the research questions'. Taking into consideration these characteristics, using purposive sampling in this research was meant to help the researcher select relevant people (teachers) to be interviewed in order for that the main goals of the study could be reached easily and efficiently.

In terms of access to participants, snowball sampling was used. As pointed out by MacNealy (1999: 157), snowball sampling can be used 'in those rare cases when the population of interest cannot be identified other than by someone who knows that a certain person has the necessary experience or characteristics to be included.' Biernacki and Waldorf (1981) claimed that it is better to use snowball sampling if the research is carried out on a sensitive issue. However, there is a disadvantage of this sampling method, since it is not seen as highly representative. Having said that, the participants of this research project were selected from different backgrounds as much as possible so as to ensure that the findings of the research can be generalised to a population, and can be more consistent. I was able to use my contacts in the region in order to access each participant who work in one of the Kurdish inhabited towns, and whose pupils mostly come from a Kurdish ethnic background.

\section{Procedure}

Informed consent was obtained from the research participants themselves. I first met each participant and explained the reason of my study and the nature of my research; emphasising the importance of their help, participation, willingness and honesty. It was made crystal clear to them that the data which was to be collected will remain completely anonymous, confidential and safe; as well as the fact that their participation would be absolutely voluntary. An informative leaflet including the main goals of my research, methodology and the importance of the 
research were given to them. This included my contact details as well. Consent form was then given with enough time (3 days at least) to decide if they would like to participate in the research or not. I then collected the consent forms during the second time we met and did the interviews with each participant. On the other hand, for the majority whom I interviewed via Skype, they were sent the required information and the consent form of the research via e-mail and they were given a 3-day period for their final decision, and then they were interviewed via Skype.

\section{Using Skype for Interviews}

As Lo Iacono et al. (2016) noted, using online technologies within academia is becoming more common with the internet being more popular in today's world. They further stated that Face Time and Skype are two of these online technologies researchers prefer to use for data collection. Berg (2007) stressed the practicality of using web-based in-depth interviews by talking about 'synchronous environments' such as video conferences and chat rooms, and 'asynchronous environments' such as the use of e-mails and messages. For him, even though the latter is rather useful for surveys, the former is very similar to face to face interview. Furthermore, conducting interviews via Skype is also practical, since it saves time and money for the researcher, and thus makes the process easier. For instance, the interviews for this research were conducted with teachers living in twelve different provinces in the east and southeast regions of Turkey, with eleven of them being not visited due to lack of funding. Thus, using Skype appeared to be 'a very convenient way of being able to maximise the research effort on a budget' (Lo Iacono et al., 2016: 8). All of these made the data collection part of this research much easier; because otherwise, it would not have been possible to collect the same amount of data from different cities.

\section{Data Analysis}

The analysis of the raw data collected through interviews began by translating (from Turkish into English) and transcribing each interview. As a native Turkish speaker, considering ethical purposes, I did translations of all interviews in order to protect the data as well as the anonymity of the participants. This process was followed by the organisation of the translated and transcribed data. Because the questions and sub-questions of the interviews were systematically designed to elicit responses of research questions posed in this research. This made the process of the categorisation of the data easier, since Miles and Huberman (1994: 432) highlighted the importance of this point by stating that 'valid analysis is immensely aided by data displays that are focused enough to permit viewing of a full data set in one location and are systematically arranged to answer the research question at hand'. In this process, coding was employed, which was simply 'the process of breaking down, examining, comparing, conceptualizing, and categorizing data' (Strauss and Corbin, 1990: 61). As a result, teachers' ideas and the concepts in the interviews were organised into codes. With this step, the data was reduced to a manageable form. Following the organisation of the data, the list of codes, ideas, and patterns were classified under different categories, all of which constituted the sub-sections of this paper.

The final step was the interpretation of the organised data. At this stage, the interpretivist approach was used, which attempts to understand the issues by using people's own interpretations, perceptions and experiences, as explained by Deetz (1996). This is because in this paper, knowledge is considered to be socially constructed by actors in society (see Putnam, 1983, Deetz, 1996). Therefore, in order to make sense of the data, the text was organised into codes and patterns, and then classified under categories was interpreted by the researcher.

\section{Teachers' Perception of Mustafa Kemal Atatürk and the Ideology of Kemalism within the Turkish Educational System}

Teachers have different views about Mustafa Kemal Atatürk. For example, a Turkish teacher commented:

Atatürk devoted his life to the independence of this country. We owe him in this case. Having said that, when we talk about Atatürk in, let's say, textbooks or in the curriculum, I admit that there is definitely some sort of exaggeration there. I believe that we should tell our students about him but it should be done in a more logical way.

It seems that the main point highlighted by those supporting this view is not about Atatürk and even Kemalism, but his 'nationalist' ideas. They believe that Atatürk's personality is definitely exaggerated in the curriculum, despite the fact that they love Atatürk, but the exaggeration in terms of nationalist ideas in the curriculum seems to be fine with them. However, some Turkish teachers think differently to their nationalist counterparts. For example, a Turkish teacher commented that:

Atatürk is the leader and founder of this country, so I don't see any problem in mentioning Atatürk in our textbooks, but it is quite popular to attack Atatürk nowadays, and this especially has been the case since the AKP came into power in 2002. So the political atmosphere of the country is now open for criticism of Atatürk. They abolished the Student Pledge for the same reason. (..) I foresee that they will try to wipe Atatürk out from everywhere in Turkey but I will make sure they won't succeed. 
For those supporting this view, Atatürk's personality appears to be a very important matter since it seems that for them he is considered as someone who created a new country and a new modern lifestyle for them, without whom these would not have been achieved. The difference here between these teachers is that some of them love Atatürk purely because he founded the Turkish state based on Turkish nationalism which - they believe - made Atatürk successful, while the others credited Atatürk himself for everything he did. In short, Atatürk can be defined as the modern and secular leader of Turkey in the minds of some, though he is certainly a great nationalist leader for the others.

In this regard, teachers' perceptions and the way they define Atatürk do indeed vary according to their ideological backgrounds. For example, Atatürk becomes a completely different character in the responses of some teachers. A Kurdish teacher argues that:

To be honest with you, I hate Atatürk. He was the person who tried to assimilate my ethnic identity. He started all of this nonsense, and we still suffer from it.

It appears that a number of Turkish and Kurdish teachers share more or less the same views on the personality of Atatürk, even though the Kurds seem to be filled with more hatred against him when compared to Turkish teachers. This might be explained by the fact that the Kurds have suffered a lot since the foundation of the Turkish Republic. These include policies such as forced assimilation attempts that were implemented in the first instance directly by Mustafa Kemal Atatürk. Another significant difference that emerges from the responses is that some Turkish teachers, unlike the Kurdish ones, gave Atatürk credit for winning the War of Independence, although they specifically mentioned that they do not like him personally.

In some Kurdish teachers' minds, the image of Atatürk is even worse when compared to the ones mentioned above. For example, a Kurdish teacher commented:

Mustafa Kemal was no different to Hitler and Mussolini. (..) I think he would have done similar things if he had as much power as Hitler. He had rather limited power and even then he has done terrible things against minorities in Turkey.

It is apparent that these teachers think about Mustafa Kemal Atatürk in a very negative way. In fact, he was compared with Adolf Hitler specifically by a number of Kurdish teachers due to the similarity between the two leaders they claimed was based on the fact that both created a 'nation' by exercising their authority over people (resulting in the emergence of the cult figure), and dealt with opposition in a ruthless way. As a matter of fact, in his recent book Atatürk in the Nazi Imagination, Ihrig (2014) claims that Atatürk and his new (Turkish) state - along with the nationalist policies implemented at the time - were taken very seriously by Hitler in nationalist sense while he created the Third Reich. Ihrig further asserts that Hitler's nationalist policies. His views on minority groups in Germany and his attempt to make himself an unquestionable leader called Führer (together with the development of a cult around his figure and an extreme ideology) were all influenced by the example of Atatürk's Turkey since '...for the Nazi texts and commentators, the new Turkey was a Führer state par excellence.' (ibid., p. 165)

On the other hand, some other teachers also commented on Atatürk's authoritarian character, but in a way that is specifically within the context of religion. For instance, a Turkish teacher said:

I personally do not want to teach Kemalism to my students. (..) In particular, Mustafa Kemal's stance against religion was very unpleasant. He tried to remove Islam and its symbols from the public sphere in Turkey and he partly succeeded in this. I cannot have any sympathy for a man like this, because I try to be a pious Muslim.

With regard to Atatürk and his position on religion, these teachers appear to be against Mustafa Kemal and Kemalism because they regard Mustafa Kemal's policies towards religion as unacceptable. In fact, pious Muslim people in general do not view Atatürk very favourably within society in Turkey, and the main reason for this is the fact that Atatürk's stance against religion was not very positive.

In his book named Atatürk: An Intellectual Biography, Hanioğlu (2011) claimed that Atatürk was not completely against religion, despite being an atheist. Instead, he was very pragmatic about it. According to him, he used Islam in times when it served his purpose such as during the War of Independence and in the process of the formation of his version of Turkish nationalism. As also mentioned by another Turkish historian Toprak (Radikal, 2012), Atatürk actually held an 'anticlerical position' against religions. It could be argued that Mustafa Kemal was in favour of the Turkified version of Islam, as he clearly saw that Islam was actually inseparable from the Turkish culture at the time. That is why he established the Directory of Religious Affairs (Diyanet İşleri Başkanlığı) under his secular authority, and he further commissioned Islamic scholars to translate the Quran (Holy Book of Islam) and Hadith (Prophet Muhammad's Sayings) into Turkish. In fact, he even dared to change the Adhan (Call to Prayer) from Arabic to Turkish in order to Turkify Islam. The aforementioned examples show a man trying to use religion for specific purposes, such as promoting Turkish nationalist ideals, rather than someone trying to destroy it. Having said this, Mustafa Kemal attempted to secularise Turkish political life in an authoritarian manner, executing Islamic scholars who resisted his reforms during the early days of the Republic.

Even though Atatürk's stance against religion is well-known in Turkey, ironically, some of the textbooks such as the Religious Culture and Moral Knowledge (e.g. 
see Kutlutürk, 2012) include sections like 'Atatürk and Religion' in which Atatürk's positive comments on Islam and the Prophet Muhammad are mentioned with quotes like 'Religion is necessary. Nations without religion cannot survive' and 'We have [such] a strong religion' (Meral, 2015). Yet, it needs to be borne in mind that there were different 'Atatürks' (see Akyol, 2014); there was the one during the Independence War, and then another during the process of the establishment of the new Turkish Republic. Before the war was won, Atatürk seemed to be a religious person, giving sermons on Fridays in the mosques, constantly claiming that he was trying to save the Sultanate and the Caliphate. However, it is known that he told one of his closest friends of his secret plans and his hidden agenda even during the war (Dündar, 2008). In fact, he later explained himself in his book, Nutuk (the Address) why he would pretend to be a defender of the Sultanate and the Caliphate: 1) it was easier to recruit people to fight in the war this way 2) he thought that people were not ready for his radical and revolutionist views during the war (Atatürk, 1970). However, Atatürk's stance against Islam after the foundation of Turkey changed radically. He tried to Turkify Islam in a ruthless way, because he seems to have come to the realisation that Islam was part of the Turkish identity then, and the only way to decrease its importance was, in his view, via its 'Turkification'.

Based on this discussion, it appears that the textbooks are trying to link Atatürk and Islam by mentioning his earlier comments on religion might well be the result of the conservative mind-set of the Ak Party government that has ruled Turkey since 2002. This is because the content of the textbooks has become more religious in some sense with the addition of new themes and quotes promoting Islam. Atatürk's quotes on Islam in the textbooks appear to be a result of this specific policy in Turkish education. Although scholars such as Cornell (2015) see the Ak Party's policy in education as an attempt at 'Islamisation' of the Turkish educational system, I argue that it is more appropriate to call it the 'Islamisation of themes' which were already present in textbooks. This is because, in general, the dominance of the Kemalist ideology in the education system (in the curriculum and educational attainments, and themes) has also been strengthened.

\section{The Effects of the Cult of Atatürk and the National Ideology of Kemalism in Education on Kurdish Pupils}

One of the Kurdish teachers commented:

My Kurdish student came to me once and told that his parents were talking about Atatürk at home, criticising him by using some harsh phrases such as 'katil' (killer). He said he started crying while they were discussing this and when he was asked what he was crying about, he told them 'Because you are criticising Atatürk but I love him. Why are you doing this?' When he told me all of this, I actually felt very bad.

The quote above clearly indicates how Kurdish students are affected by the ideology-driven Turkish national education. With this in mind, this demonstrates that the Turkish national educational system shapes these students' personalities by reconstructing their mental state through the ideological curriculum, and by doing so, the main goal of the national education - which is to create a generation following Atatürk's path sincerely - seems to be accomplished in some sense, at least at the primary school level.

On the other hand, this example also shows that the effects of the implementation of the ideology-driven national education on the Kurds are very serious, as the story above shows the ways in which the Kemalist propaganda within education could potentially foment a negative relationship within Kurdish families. In addition to a possible conflict within families, another type of conflict may also become a serious matter between families/parents and teachers, as another anecdote mentioned by a Turkish teacher shows:

While I was talking about Atatürk's life in the classroom one day, one of my Kurdish students said something in Kurdish that I did not understand. After the class, I tried to find out what he said and I learned from his friends that he actually said 'Biji Serok', and my Kurdish colleagues said this automatically means 'Long Live Abdullah Öcalan' when the phrase is used without a specific name by a Kurd. Of course, I got very angry and asked his parents to come to the school as soon as possible. When they came, I was very straightforward, telling them this is something that cannot be tolerated in the classroom. They did not say much and left embarrassedly. (..)

It is evident from the quote that teachers and parents experience unpleasant and awkward social situations over controversial issues caused by the ideological character of the education system. This further appears to be a functional example showing that the indoctrination through the Turkish nationalism-oriented curriculum not only affects Kurdish students, but their families as well. Likewise, a similar anecdote was mentioned by a Turkish teacher who says:

When I was teaching the 'History of the Turkish Revolution and Kemalism' course unit, my Kurdish student asked me 'My teacher! Did Atatürk really kill Islamic scholars?' A pupil at that age cannot ask a question like this without someone telling him this kind of information. I guessed he might have heard this from his family.

This quote, a slightly different version of the former one, also indicates a similar probable 'parents-teachers (family-school) conflict'. These further suggest that 
schools are seen as one of the main departments of the state wherein the dictation of the hegemonic ideology takes place; teachers are seen as the agents of the educational authority that operates in a way that leads to the assimilation of all citizens other than Turks. On the other hand, these examples can also be interpreted as examples of the reactions of Kurdish parents/families to such designs, as it seems that Kurdish parents try to neutralise or at least minimise the negative impacts of the Turkish educational system on their children. It is quite normal for Kurdish families to show a reaction in this case, as they may be worried that their children might be assimilated into the hegemonic culture, that is, Turkishness.

The creation of a new 'cult' of Abdullah Öcalan within Kurdish nationalism (see Tezcür, 2013) might actually be explained by the Kurds' reaction to the hegemonic Turkish culture and the cult of Atatürk that is visible everywhere in Turkey, ranging from schools to streets. As a matter of fact, this statement can further be reinforced by one example given by a Turkish teacher:

I remember we were reading a poem about Atatürk in the textbook once and my Kurdish student told me in front of the class 'Atatürk is not my leader, my real leader is Abdullah Öcalan'. I can certainly understand how they can feel like this with our current education system. I suppose I also sometimes feel a similar thing to this '[i.e.,] this man is not my leader, somebody else is'.

The example above shows that some Kurdish students do react to what is being taught in schools. Additionally, as mentioned in another recent study conducted by Can et al. (2012), one of the teachers interviewed commented that "the textbooks talk about "a Turkish child" in poems. Some students argue against it, saying that it should actually be “all children”...' (p. 34). Likewise, some teachers who interviewed in this study mentioned that they have witnessed many times that some Kurdish students recited the latter statement in the Student Pledge (which has now been abolished by the government) as 'How happy is the one who says I am Kurdish', instead of the official 'How happy is the one who says I am Turkish'. Many Kurdish students did not recite it at all.

One of the teachers who used to work in the western part of Turkey commented that:

Since I have worked in the western part of Turkey, I can actually compare the perceptions of Turkish and Kurdish pupils. My Turkish students would admire Atatürk, they would simply love him and I did not have any problem regarding teaching Atatürk or anything like that, but my Kurdish students seem confused, and I sometimes feel awkward when teaching - you know - Atatürk, his life, his principles et cetera.

This comment draws a clear distinction between Turkish and Kurdish pupils on their perception of Mustafa Kemal Atatürk. One of the issues that emerges from these is that while Kurdish pupils might potentially react to the ideological culture dominated by Kemalism and its interpretation of nationalism, which is constructed through the ideology-driven educational system, Turkish pupils seem to tend towards internalising/embracing the ideology, including the aggrandisement of Atatürk's personality and the exaggeration of his ideology, Kemalism, with its nationalist and sometimes even racist discourse. In her postgraduate work titled Reading of Turkish Modernisation: Primary School Children's Perception of Atatürk, Elmas (2007) examined Turkish primary school pupils' perception of Atatürk constructed both in the schooling environment and in daily life. The study mentions the main keywords used by participants when talking about Atatürk as 'saver' (20 times), 'leader' (19 times), 'sun' or 'light' (18 times) 'clever' or 'intelligent' (18 times) respectively (ibid., p. 41). She further stated that the current education system in Turkey, with a huge reference to the cult of Atatürk, results in the creation of a 'sacred and secular' (laic) figure within students' minds. Hence, she concluded that, 'schools in this system become a holy place (chapel) under the symbolic domination of Atatürk' (ibid., p. 62).

\section{Nationalist Themes in the Textbooks}

Nationalist themes are everywhere in the textbooks, they are not just in the social sciences course units, you can even find something in maths, which is strange, but it certainly shows that how nationalist our education system is.

A Kurdish teacher

There are nationalist themes in the textbooks, because it is our national education (he laughs)... I do not understand why this should be wrong. Other countries also want to educate their youth according to their nationalist ideals. If I live in one of those countries, I cannot criticise anyone for being a nationalist, because it is who they are.

A Turkish teacher

These two comments reflect the main positions on the issue of the existence of the nationalist themes in the textbooks. The former quote represents the first position which argues that nationalist themes are over emphasised in the current textbooks, and that this is a huge mistake, while the latter represents the second position which defends the idea that Turkish education is nationalist and that it should remain nationalist because there is nothing wrong with this.

It is true that Kemalism not only dominates the education system with the cult of Atatürk, but also with its nationalist discourse, too (see Aycan, 2005, Ince, 2012, Çayır, 2015). Turkish nationalism within the Kemalist ideology is very visible and powerful; indeed, one of the six pillars Kemalism was built upon is nationalism 
(Yeşilova, 2010). However, 'nationalism' within the Kemalist discourse appears to be an ambiguous concept, which is usually referred to as 'Atatürk nationalism', as stated in the Turkish Constitution too.

Some teachers defend the assumption that Atatürk nationalism is not based on ethnicity, instead, it is rather a supranational identity that is inclusive of every Turkish citizen, as they claim that Atatürk defined the Turkish nation as something constituted by every Turkish citizen. Having looked at the textbooks, Atatürk nationalism is similarly - defined as being inclusive of all ethnicities, and not being racist. Nevertheless, when the textbooks mention the Turkish nation, they do talk about it within a historical context with a specific focus on the 'Turkish ethnicity', and they further talk about 'external Turks' living in other countries. In other words, the Turkish nation and Turkishness are clearly mentioned as an ethnic identity in the textbooks. Therefore, even though it is claimed that the Turkishness is not an ethnic entity, it is, per contra, mentioned very visibly that it is an identity that is only related to the Turks, and Atatürk nationalism thus automatically becomes an ethno-cultural nationalism in this case. Hence, for the time being, the textbooks and the curriculum, in this regard, contradict one another.

Teachers' and students' experiences also prove that Atatürk nationalism promotes the Turkish ethnicity alone, and excludes all others existing in Turkey. What is more, the textbooks also mention the Turkish nation as being a great and glorious one. In fact, the virtues referring to the Turkish nation may well be considered as racist. Phrases like '... in your noble blood' and 'the clever Turkish nation' are very common in the textbooks.

Considering the ethno-cultural nationalism that is embedded within Kemalist ideology, which is referred to as Atatürk nationalism, the Kurdish people appear to be the victims of this hegemonic nationalist discourse more than others, as they are by far the biggest minority ethnic group in Turkey. Therefore, the negative impact of the Turkish education on the Kurds is a particular serious matter worthy of discussion.

One of the Kurdish teachers gave an example, which is as follows:

One day, I was sitting in the garden of my school during the noon break, I was a bit sad on that day, and one of my students approached me. He said to me 'My teacher! Please do not feel sorry. I know you are Kurdish, but you are a good person.' I was really shocked and did not know what to say. This memory usually comes to my mind and makes me very sad. (..) [the student] was Kurdish (he then laughs).

Likewise, Can et al. (2012: 32) mentions another similar example given by a Kurdish teacher working in Istanbul:

One of my students was always denigrating the Kurds in the classroom, saying things like 'They kill our soldiers. They are bad people', words that are full of hate. I later met his mother. She told me that she was a migrant and her husband is actually Kurdish. I was astonished. I learned that he also argues with his father when his father talks with his mother on the phone in Kurdish, saying 'Why are you speaking in Kurdish. Shut up. I do not want to hear that.' I am wondering whether there is any other ethnic group hates its own ethnicity. (..) Being Kurdish is regarded as being unsuccessful and ignorant.

It has also been mentioned in the same study that a Kurdish mother living in Istanbul said that her son wants her not to wear a white headscarf when she goes to school to meet teachers, because other students could identify that she is Kurdish in that case. Besides, he also wants his mother to speak 'proper Turkish' with his teachers (ibid., p 42).

Having looked at the aforementioned examples regarding Kurdish identity, the alienation of Kurdish identity in the Turkish educational system seems to be one of the main causes here. Considering the literature, Kurdish students at early stages including primary, secondary and high schools do indeed feel ashamed of their ethnic and cultural identity (Coşkun et al., 2010). They often try hard to look Turkish in all aspects of daily life. In this regard, the Turkish educational system operates make the Kurdish students ashamed of their own identity and even hate it.

\section{Findings and Discussions}

The findings of this study show that teachers' perceptions about the cult of Atatürk are predominantly negative -apart from very few teachers, with all others were not sympathetic to Mustafa Kemal Atatürk. Furthermore, when it comes to the cult of Atatürk and the Kemalist ideology that are embedded within the Turkish educational system, the overwhelming majority of the interviewees including the ones who had rather nationalist views on most of the issues, agreed with the idea that there is certainly an overemphasis on these matters within both the curriculum and the textbooks.

This paper also showed that the cult of Atatürk and the Kemalist interpretation of nationalism have such serious effects on Kurdish pupils, which may further possibly affect their well-beings as well as the reproduction of their ethnic culture. Kurdish identity seems to be degraded in this case against the 'superiority' of Turkishness that is promoted in the Turkish educational system.

The excessive use of Atatürk narratives in the Turkish educational system not only has a negative impact on Kurdish pupils, but also on Turkish pupils, too. In particular, pupils in primary schools might well be influenced by the cult of Atatürk narratives in a cognitive sense. To illustrate this, Turkish columnist Hakkı Yalçın wrote an article in 2010, publishing some of the letters written by primary school pupils to Atatürk himself for the purpose of remembering him during the anniversary of his death. Some of the striking examples are as follows: 
I know that you see and hear me, my (founding) father. I drink my milk every morning and I do my homework (An 8 years old girl)

People who sit in your seat make my father and mother cry. Can you help us my (founding) father? (A 7 years old girl)

They even stole our children's day from us. Please say something to them. (A 10 years old boy) (Yalçın, 2010)

These short examples clearly indicate that there is a serious issue of children developing worrying perceptions about Atatürk, as pupils tend to see himself as an extraordinary person who despite his death, continues to have the power to help them.

Another significant finding revealed in this study is that Kurdish students' reaction to the existing curriculum seems to create another 'nationalism' amongst Kurds, whereby all the characteristics of Turkish nationalism, such as the cult of a leader and the exaggeration of the national attributes, can similarly be observed. The phrase 'Biji Serok' used by one of Kurdish pupils offers a window into another crucial issue - that is the reproduction of the hegemonic culture in a dominated community in a different form. In this case, the idea of having 'one' great leader for the Turks (Atatürk) seems to be reproduced within the Kurdish national movement for the Kurds (Abdullah Öcalan). This can be seen, for example, in the new curriculum and textbooks recently introduced by the Partiya Yekitiya Demokrat (Democratic Union Party - PYD), the Syrian affiliate of the $\mathrm{PKK}$, in the regions they rule in Northern Syria. The newly introduced curriculum is causing controversy over its promotion of Abdullah Öcalan and his ideological tenants, as well as for including biased information. Indeed, other Kurdish political parties in the region, such as the Kurdish National Council (KNC), accuse the PYD of implementing a curriculum that is too ideological (Syria Direct, 2015). The new textbooks include sections such as 'Öcalan Philosophy', with long passages devoted to Abdullah Öcalan's saying and including many photographs of him. Therefore, as mentioned by the secretary of the West Kurdistan Teachers' Union, Jian Zakaria, this ideology-driven national curriculum has the potential to foster a kind of 'totalitarian ideology' within classrooms 'by sanctifying the leader and militarising the schools' (Syria Direct, 2015: 1). This is precisely what has been happening in Turkish schools since the 1920s. This ideology created by the Kurds might well be interpreted as a kind of micro-nationalism that is constructed through imitating the hegemonic culture of the official nationalism in Turkey, that is, the national ideology of Kemalism and its interpretation of Turkish nationalism.

One of the interesting findings is that the excessive emphasis on the cult of Mustafa Kemal Atatürk, which often leads to the sanctification of his personality, appears to have some undesirable impact on the Turkish pupils, too. Given the fact that Atatürk is portrayed as an extraordinary person and a near super-hero in textbooks, the relationship between students and Atatürk becomes even more complicated and thus more controversial than is usually admitted. My findings are consistent with those of Elmas (2007) who concludes that this relationship has a 'metaphysical and mystical dimension', and 'regularly repeated Atatürk-centred rituals both inside and outside the school', and the state of Atatürk within the physical atmosphere of the school altogether make Atatürk a celestial and mystical figure, or even a divine figure in pupils minds so to say (ibid., p. 36).

The cult of Mustafa Kemal Atatürk could actually be seen in many people's minds. For example, Özyürek (2006) examined the guest books of the exhibition named 'To Create a Citizen' displaying objects about Atatürk. A university student wrote the following note:

I love you,

I am thankful that you taught me and others how to think and how to be a human. But there are some people who misunderstand your principles and ideas. I am sure your bones are aching in your grave. I am a second year student in a dental school. (...) I am sure you will reincarnate (reenkerne olursun) one day. I am waiting for that day. It will be a lot of fun. Atam, please cut off your peace and do something. You can do it. I am really sick of these people. They are all nutcases who hide behind your principles. I want you back.

Trying to be a student (p. 102).

These examples only show how 'the cult of Atatürk' that is promoted by the Turkish state, and that is visible in public places might make people even 'paranoid'. Thus, considering the negative effects of the cult of Atatürk in the education system, there appears to be two major consequences for Turkish and Kurdish pupils. These are: 1) to make Turkish pupils sanctify Atatürk, something culminates in the unquestionable authority, and thus to make them become sincere Kemalists by using this authority. With a strong sense of Turkish nationalism which becomes internalised (Elmas, 2007), and 2) to make Kurdish pupils become assimilated into the Turkish culture, by making them forget their language and culture, which usually leads to them becoming passive persons who are ashamed of being who $\mathrm{s} / \mathrm{he}$ is in the first place. This eventually makes them become very different people who feel a deep hatred against the hegemonic Turkish culture after they finish their schools and go to university. With the rise of both Turkish and Kurdish nationalism in society, the polarisation between the Turkish and Kurdish nationalists becomes more visible (Taspinar, 2005). Therefore, it could be argued that Turkey's efforts to maintain a unitary state entity, which is one of the major goals of the Turkish educational system and one of the obsessions in society, is actually feeding the idea of separatism more than the idea of unity. It is, therefore, possible to hypothesise that the state-driven and Kemalism-oriented national educational system threatens the likelihood of national cohesion in 
Turkey.

Finally, considering all of the issues discussed in this paper, in order to understand the key issues in the Turkish educational system, the relationship between 'power' and 'knowledge', as characterised by Foucault (1978), may be considered, and especially his argument about the link between knowledge, which is created by discourse, and power. In the Turkish case, knowledge is created by the Kemalist nationalist discourse, which then becomes 'power' shaping/determining relationships amongst individuals within society. With this power, the national ideology of Kemalism maintains its privileged positions over other ideologies existing in society.

\section{REFERENCES}

[1] AKYOL, T. 2014. Ama Hangi Atatürk?, Istanbul, Doğan Kitap.

[2] ATATÜRK, K. 1970. Nutuk, Istanbul, Milli Eğitim Basımevi.

[3] AYCAN, N. 2005. The process of getting identity in Turkish society: Kemalist education. Journal of Social Sciences, 136-140.

[4] BABBIE, E. 1990. Survey Research Methods, California, Wadsworth Publishing.

[5] BERG, B. L. 2007. Qualitative research methods for the social sciences [6th edition], Boston, Pearsons Education.

[6] BIERNACKI, P. \& WALDORF, D. 1981. Snowball sampling: Problems and Techniques of Chain Referral Sampling. Sociological Methods and Research, 10(2), 141-163.

[7] BORA, T. 2017. Cereyanlar - Türkiye'de Siyasi İdeolojiler, Istanbul, İletişim.

[8] CAN, B., GÖK, F. \& ŞIMŞEK, S. 2012. Toplumsal Barışın İnşasında Ögretmenlerin Rolü, Kürt Meselesi Okula Nasıl Yansıyor?, Istanbul, Helsinki Yurttaşlar Derneği.

[9] ÇAYIR, K. 2015. Citizenship, nationality and minorities in Turkey's textbooks: from politics of non-recognition to 'difference multiculturalism'. Comparative Education, 51 (4), 519-536.

[10] CIA WORLD FACTBOOK. 2014. CIA 2014 World Factbook [Online]. Available: https://www.cia.gov/library/ publications/download/download-2014 [Accessed 17 October 2016].

[11] CORNELL, S. E. 2015. The Islamization of Turkey: Erdoğan's Education Reforms. Turkey Analyst, 8(16).

[12] COŞKUN, V., DERINCE, M. Ş. \& UÇARLAR, N. 2010. Dil Yarası: Türkiye'de Eğitimde Anadilinin Kullanılmaması Sorunu ve Kürt Ögrencilerin Deneyimleri, Diyarbakır, DİSA Yayınları.

[13] DAVID, M. \& SUTTON, C. D. 2004. Social Research the Basics, London, SAGE Publications.
[14] DEETZ, S. 1996. Deetz, S. "Describing differences in approaches to organization science: Rethinking Burrell and Morgan and their legacy”. Organization Science, 7(2), 191-207.

[15] DENZIN, N. K. \& LINCOLN, Y. S. 2000. 'Introduction: The discipline and practice of qualitative research'. In: DENZIN, N. K. \& LINCOLN, Y. S. (eds.) Handbook of qualitative research. California: SAGE Publications.

[16] Mustafa, 2008. Directed by DÜNDAR, C.

[17] ELMAS, E. 2007. "Sevgili Atatürkçügüm": İlkokul Çocuklarında Atatürk Algısı, Istanbul, Hayy Kitap.

[18] FOUCAULT, M. 1978. The History of Sexuality [translated by R.Hurley], New York, Penguin Books.

[19] GAMBETTI, Z. 2008. Decolonising Diyarbakır: culture, identity and the struggle to appropriate urban space. In: ASDAR AL, K. \& RIEKER, M. (eds.) Re-exploring the Urban: Comparative Citispaces in the Middle East and South Asia. Karachi: Oxford Universty Press.

[20] GLYPTIS, L. 2008. Living up to the father: The national identity prescriptions of remembering Atatürk; his homes, his grave, his temple. National Identities, 10(4), 353-372.

[21] GRAY, D. E. 2004. Doing Research in the Real World, London, SAGE Publications.

[22] HANIOĞLU, Ş. 2011. Atatürk: An Intellectual Biography, Princeton and Oxford, Princeton University Press.

[23] IHRIG, S. 2014. Atatürk in the Nazi Imagination, Harvard, Harvard Universty Press.

[24] INCE, B. 2012. Citizenship and Identity in Turkey: From Ataturk's Republic to the Present Day, New York, I.B.Tauris.

[25] KONDA. 2010. Kürd Meselesini Yeniden Düşünmek [Online]. Available:http://www.konda.com.tr/tr/raporlar/20 10_12_KONDA_Kurt_Meselesini_Yeniden_Dusunmek.pd $\mathrm{f}$ [Accessed 20 October 2016].

[26] KUTLUTÜRK 2012. Din Kültürü ve Ahlak Bilgisi 6, Ankara, MEB Yayınları.

[27] LO IACONO, V., SYMONDS, P. \& BROWN, D. H. K. 2016. Skype as a Tool for Qualitative Research Interviews. Sociological Research Online, 21(2), 1-12.

[28] MACNEALY, M. S. 1999. Strategies for Empirical Research in Writing, New York, Longman.

[29] MASON, J. 1996. Qualitative Researching, London, SAGE Publications.

[30] MATEESCU, D. 2006. Kemalism in the Era of Totalitarianism: A Conceptual Analysis. Turkish Studies, 7(2), 225-241.

[31] MCDOWALL, D. 2003. A modern history of the Kurds, New York, I.B.Tauris.

[32] MERAL, Z. 2015. Compulsory Religious Education in Turkey: A Survey and Assessment of Textbooks. US Commission on International Religious Freedom.

[33] MILES, M. B. \& HUBERMAN, A. M. 1994. Qualitative Data Analysis (2nd edition), Thousand Oaks, CA, SAGE 
Publications.

[34] MINISTRY OF NATIONAL EDUCATION. 2012. The Basic Law of National Education [Online]. Available: http://mevzuat.meb.gov.tr/html/temkanun_0/temelkanun_0. html [Accessed 17 May 2013].

[35] ÖZYÜREK, E. 2006. Nostalgia for the Modern: State Secularism and Everyday Politics in Turkey, Durham, Duke University Press.

[36] PUTNAM, L. L. 1983. The intrepretive perspective: An alternative to functionalism. In: PUTNAM, L. L. \& PACANOWSKI, M. E. (eds.) Communications in organizations, an interpretive approach. Beverly Hills: CA: SAGE.

[37] RADIKAL. 2012. Atatürk'ün Kürt sorunu değil, din sorunu vardl (9 April 2012) [Online]. Available: http://www.radikal.com.tr/yazarlar/ezgi-basaran/ataturkunkurt-sorunu-degil-din-sorunu-vardi-1084339/ [Accessed 12 November 2015].

[38] SIRKECI, İ. 2006. The Environment of Insecurity in Turkey and the Emigration of Turkish Kurds to Germany, New York, Edwin Mellen Press.

[39] STRAUSS, A. L. \& CORBIN, J. 1990. Basics of Qualitative Research, Newbury Park, California, SAGE Publications.

[40] TASPINAR, O. 2005. Kurdish nationalism and political Islam in Turkey: Kemalist identity in transition, Psychology Press.

[41] TEZCÜR, G. M. 2013. Prospects for Resolution of the Kurdish Question: a realist perspective. Insight Turkey, 15, $68,1302-177 X$.

[42] YALÇIN, H. 2010. Ata'ya mektuplar [10 November 2010] [Online]. Available: http://www.takvim.com.tr/yazarlar/hak ki_yalcin/2010/11/10/ataya_mektuplar [Accessed 17 April 2016].

[43] YEŞILOVA, H. 2010. Kemalism: Ideology, Tutelary Regime, and Incompatibilities. Turkish Journal of Politics, 1(2), 37-49.

[44] ZÜRCHER, E. J. 2007. Turkey: A Modern History, London, New York, I.B.Tauris.

[45] AKYOL, T. 2014. Ama Hangi Atatürk?, Istanbul, Doğan Kitap.

[46] ATATÜRK, K. 1970. Nutuk, Istanbul, Milli Eğitim Basımevi.

[47] AYCAN, N. 2005. The process of getting identity in Turkish society: Kemalist education. Journal of Social Sciences, 136-140.

[48] BABBIE, E. 1990. Survey Research Methods, California, Wadsworth Publishing.

[49] BELGE, M. 2004. Mustafa Kemal ve Kemalizm. In: İNSEL, A. (ed.) Kemalizm. Istanbul: İletişim.

[50] BERG, B. L. 2007. Qualitative research methods for the social sciences [6th edition], Boston, Pearsons Education.

[51] BIERNACKI， P. \& WALDORF， D. 1981. Snowball sampling: Problems and Techniques of Chain Referral Sampling. Sociological Methods and Research, 10(2),
$141-163$

[52] BILTEKIN, G. 2007. Non-material Soruces of Turkish Armed Forces' Political Power: a "Military in Society" approach. unpublished MA dissertation, Bilkent University.

[53] BORA, T. 2017. Cereyanlar - Türkiye'de Siyasi Ídeolojiler, Istanbul, İletişim.

[54] CAN, B., GÖK, F. \& ŞIMŞEK, S. 2012. Toplumsal Barışın Inş̧asında Ögrretmenlerin Rolü, Kürt Meselesi Okula Nasıl Yansıyor? , Istanbul, Helsinki Yurttaşlar Derneği.

[55] ÇANDAR, C. 2000. Ataturk's Ambitious Legacy. The Wilson Quarterly, 24: 4.

[56] ÇAYIR, K. 2015. Citizenship, nationality and minorities in Turkey's textbooks: from politics of non-recognition to 'difference multiculturalism'. Comparative Education, 51 (4), 519-536.

[57] CIA WORLD FACTBOOK. 2014. CIA 2014 World Factbook [Online]. Available: https://www.cia.gov/library/ publications/download/download-2014 [Accessed 17 October 2016].

[58] CORNELL, S. E. 2015. The Islamization of Turkey: Erdoğan's Education Reforms. Turkey Analyst, 8(16).

[59] COŞKUN, V., DERINCE, M. Ş. \& UÇARLAR, N. 2010. Dil Yarası: Türkiye'de Eğitimde Anadilinin Kullanılmaması Sorunu ve Kürt Öğrencilerin Deneyimleri, Diyarbakır, DİSA Yayınları.

[60] DAVID, M. \& SUTTON, C. D. 2004. Social Research the Basics, London, SAGE Publications.

[61] DEETZ, S. 1996. Deetz, S. "Describing differences in approaches to organization science: Rethinking Burrell and Morgan and their legacy”. Organization Science, 7(2), 191-207.

[62] DENZIN, N. K. \& LINCOLN, Y. S. 2000. 'Introduction: The discipline and practice of qualitative research'. In: DENZIN, N. K. \& LINCOLN, Y. S. (eds.) Handbook of qualitative research. California: SAGE Publications.

[63] Mustafa, 2008. Directed by DÜNDAR, C.

[64] ELMAS, E. 2007. "Sevgili Atatürkçü̆̆üm": İlkokul Çocuklarında Atatürk Algısı, Istanbul, Hayy Kitap.

[65] ERICKSON, E. 2001. Ordered to Die: A History of the Ottoman Army in the First World War, Westport, Greenwood Press.

[66] FOUCAULT, M. 1978. The History of Sexuality [translated by R.Hurley], New York, Penguin Books.

[67] GAMBETTI, Z. 2008. Decolonising Diyarbakır: culture, identity and the struggle to appropriate urban space. In: ASDAR AL, K. \& RIEKER, M. (eds.) Re-exploring the Urban: Comparative Citispaces in the Middle East and South Asia. Karachi: Oxford Universty Press.

[68] GLYPTIS, L. 2008. Living up to the father: The national identity prescriptions of remembering Atatürk; his homes, his grave, his temple. National Identities, 10(4), 353-372.

[69] GRAY, D. E. 2004. Doing Research in the Real World, London, SAGE Publications. 
[70] GUTTSTADT, C. 2013. Turkey, the Jews and the Holocaust, New York, Cambridge Universty Press.

[71] HANIOĞLU, Ş. 2011. Atatürk: An Intellectual Biography, Princeton and Oxford, Princeton University Press.

[72] HARRIS, G. 1965. The Role of the Military in Turkish Politics Part I. The Middle East Journal, 19(1), 54-66.

[73] IHRIG, S. 2014. Atatürk in the Nazi Imagination, Harvard, Harvard Universty Press.

[74] INCE, B. 2012. Citizenship and Identity in Turkey: From Ataturk's Republic to the Present Day, New York, I.B.Tauris.

[75] İNSEL, A. (ed.) 2004. Kemalizm, Istanbul: İletişim.

[76] KONDA. 2010. Kürd Meselesini Yeniden Düşünmek [Online]. Available:http://www.konda.com.tr/tr/raporlar/20 10_12_KONDA_Kurt_Meselesini_Yeniden_Dusunmek.pd f [Accessed 20 October 2016].

[77] KUTLUTÜRK 2012. Din Kültürü ve Ahlak Bilgisi 6, Ankara, MEB Yayınları.

[78] LO IACONO, V., SYMONDS, P. \& BROWN, D. H. K. 2016. Skype as a Tool for Qualitative Research Interviews. Sociological Research Online, 21(2), 1-12.

[79] MACNEALY, M. S. 1999. Strategies for Empirical Research in Writing, New York, Longman.

[80] MASON, J. 1996. Qualitative Researching, London, SAGE Publications.

[81] MATEESCU, D. 2006. Kemalism in the Era of Totalitarianism: A Conceptual Analysis. Turkish Studies, $7(2), 225-241$.

[82] MCDOWALL, D. 2003. A modern history of the Kurds, New York, I.B.Tauris.

[83] MELSON, R. 1990. Provocation or Nationalism: A Critical Inquiry into the Armenian Genocide of 1915. In: CHALK, F. R. \& JONASSOHN, K. (eds.) The History and Sociology of Genocide: Analyses and Case Studies. New Haven: Yale Unievrsity Press.

[84] MERAL, Z. 2015. Compulsory Religious Education in Turkey: A Survey and Assessment of Textbooks. US Commission on International Religious Freedom.

[85] MILES, M. B. \& HUBERMAN, A. M. 1994. Qualitative Data Analysis (2nd edition), Thousand Oaks, CA, SAGE Publications.

[86] MINISTRY OF NATIONAL EDUCATION. 2012. The Basic Law of National Education [Online]. Available: http://mevzuat.meb.gov.tr/html/temkanun_0/temelkanun_0. html [Accessed 17 May 2013].

[87] ÖZYÜREK, E. 2006. Nostalgia for the Modern: State Secularism and Everyday Politics in Turkey, Durham, Duke University Press.

[88] PUTNAM, L. L. 1983. The intrepretive perspective: An alternative to functionalism. In: PUTNAM, L. L. \& PACANOWSKI, M. E. (eds.) Communications in organizations, an interpretive approach. Beverly Hills: CA: SAGE.
[89] RADIKAL. 2012. Atatürk'ün Kürt sorunu değil, din sorunu vardl (9 April 2012) [Online]. Available: http://www.radikal.com.tr/yazarlar/ezgi-basaran/ataturkunkurt-sorunu-degil-din-sorunu-vardi-1084339/ [Accessed 12 November 2015].

[90] SIRKECI, İ. 2006. The Environment of Insecurity in Turkey and the Emigration of Turkish Kurds to Germany, New York, Edwin Mellen Press.

[91] STRAUSS, A. L. \& CORBIN, J. 1990. Basics of Qualitative Research, Newbury Park, California, SAGE Publications.

[92] TASPINAR, O. 2005. Kurdish nationalism and political Islam in Turkey: Kemalist identity in transition, Psychology Press.

[93] TEZCÜR, G. M. 2013. Prospects for Resolution of the Kurdish Question: a realist perspective. Insight Turkey, 15, $68,1302-177 X$.

[94] TURAN, Ş. 1999. Atatürk'ün Düşünce Yapısını Etkileyen Olaylar, Ankara, TTK Yayınları.

[95] ÜNDER, H. 2004. Atatürk İmgesinin Siyasal Yaşamdaki Yeri. In: İNSEL, A. (ed.) Kemalizm. Istanbul: İletişim.

[96] UYAR, H. 2004. Mahmut Esat Bozkurt. In: INSEL, A. (ed.) Kemalizm. Istanbul: İletişim.

[97] YALÇIN, H. 2010. Ata'ya mektuplar [10 November 2010] [Online]. Available: http://www.takvim.com.tr/yazarlar/hak ki_yalcin/2010/11/10/ataya_mektuplar [Accessed 17 April 2016].

[98] YAVUZ, M. H. \& ESPOSITO, J. L. 2003. Turkish Islam and the secular state: The Gülen movement, New York, Syracuse University Press.

[99] YEŞILOVA, H. 2010. Kemalism: Ideology, Tutelary Regime, and Incompatibilities. Turkish Journal of Politics, $1(2), 37-49$.

[100] ZÜRCHER, E. J. 2007. Turkey: A Modern History, London, New York, I.B.Tauris.

${ }^{\mathrm{i}}$ Dr Adem Ince is an Assistant Professor in the School of Education at Siirt University, Turkey. He completed his Ph.D. in November 2016 in Sociology at the University of Leeds, where his work focused on the relationship between the national educational system and the Kurdish question in Turkey. He holds a master's degree from the University of Manchester in International Education. 